ОБ АСПЕКТАХ ПСИХОЛОГИИ ДОПРОСА НЕСОВЕРШЕННОЛЕТНИХ

\title{
ABOUT ASPECTS OF THE PSYCHOLOGY OF INTERROGATION OF A MINOR
}

\author{
БЕРКОВИЧ О.Е., \\ БУТЫРСКАЯ А.В., \\ ЛЯЛЕВА Е.С. \\ ФГАОУ ВО ННГУ им.Н.И.Лобачевского \\ BERKOVICH O.E., \\ BUTIRSKAYA A.V., \\ LYALEVA E.S.
FSAEI of HE NNU named after NI Lobachevsky

vikapsds17@gmail.com

doi: $10.18411 /$ pivsn-03-2019-39

idsp: sciencepub-pivsn-03-2019-39

\section{АННОТАЦИЯ}

В статье рассматриваются особенности проведения допроса несовершеннолетних, индивидуально - психологические особенности возрастных групп. Особенности поведения несовершеннолетних в процессе допроса, позволяющие следователю установить психологический контакт с ними с целью получения правдивых показаний.

КЛЮЧЕВЫЕ СЛОВА: несовершеннолетний, возрастные и индивидуальные особенности допрашиваемого лица, психологические приёмы воздействия, психологический контакт, допрос.
\end{abstract}

\section{ANNOTATION}

The article deals with the peculiarities of interrogation of minors, individual psychological characteristics of age groups. Features of behavior of minors in the course of interrogation allowing the investigator to establish psychological contact with them for the purpose of obtaining truthful indications.

KEY WORDS: minor, age and individual characteristics of the interrogated person, psychological methods of influence, psychological contact, interrogation.

\section{ВВЕДЕНИЕ}

Актуальность настоящей статьи обусловлена тем, что с каждым годом в Российской Федерации количество преступлений, совершенных с участием несовершеннолетних, растет. По данным МВД России почти каждое двадцать седьмое (3,7\%) расследованное преступление совершено несовершеннолетними или при их соучастии. За первые девять месяцев 2018 года органами правопорядка было выявлено 29 397 несовершеннолетних правонарушителей.

\section{ЦЕЛЬ ИССЛЕДОВАНИЯ}

Юридико-психологической науке и практике известно процесс расследования преступлений, совершенных несовершеннолетними, достаточно сложный, поэтому требует от следователя специальных знаний из области детской и подростковой психологии и педагогики. Любое расследуемое преступление начинается с допроса, в ходе которого можно получить ценную информацию для разработки версий и планирования расследования. С целью получения правдивых показаний важно знать специфику допроса несовершеннолетних, которая связана с их возрастными, гендерными, индивидуальными психологическими особенностями. 


\section{РЕЗУЛЬТАТЫ И ОБСУЖДЕНИЕ}

Как показывает практика, трудности при производстве допроса несовершеннолетних подозреваемых и обвиняемых испытывает почти половина сотрудников различных служб органов внутренних дел (следователи, дознаватели, участковые уполномоченные полиции, сотрудники уголовного розыска, инспекторы подразделений по делам несовершеннолетних). Основной причиной данных затруднений является недостаток психологических знаний, которые необходимы им для выполнения служебных обязанностей. Каждый второй сотрудник обратился бы к психологу за помощью в установлении психологического контакта с несовершеннолетним, составлении перечня вопросов при подготовке к допросу, оказании психологопедагогического воздействия на него.

Мы согласны с мнением большинства исследователей в области юридической психологии в том, что ведущей потребностью несовершеннолетних является потребность в самоутверждении. Обычно это происходит в пределах малой компании, что может повлечь негативные последствия. Подросток старается подражать своим товарищам, следовательно, изменяется его поведение или мнение под их воздействием (повышенная конформность).

Наше исследование подтвердило гипотезу о том, что негативизм, грубость, упрямство, демонстрация независимости - могут побудить несовершеннолетних из внешне благополучных семей к антисоциальному поведению. Подросток хочет сделать все наперекор родителям, доказать свою взрослость и независимость. В итоге подросток находит для себя среду, в которой принимают его желание быть «взрослым».

Как известно, в пубертантном периоде личности часто свойственно любопытство, склонность к рискованным действиям, жажда приключения и бравада, что может спровоцировать ее к совершению преступления.

К индивидуальным личностным чертам несовершеннолетних принято относить доверчивость, неумение выходить из конфликтных жизненных ситуаций, приспосабливаться к конкретным условиям жизни, что становится причиной совершения преступлений под воздействием опытных преступников.

Мы согласны с точкой зрения В.С. Мухиной о том, что в целом подростковому возрасту человека свойственно двойственное состояние: «Именно в юности происходит восхождение человека до высочайшего потенциала человечности и духовности, но именно в этом возрасте человек может опуститься до самых мрачных глубин бесчеловечности»[1].

Исходя из озвученной научной позиции, допрос несовершеннолетних необходимо проводить в зависимости от гендерной принадлежности. Так, согласно результатам зарубежных и отечественных исследований, половые различия обусловлены строением мозга, гормональными и соматическими особенностями представителей различных полов, условиями их воспитания и влияния социальной среды [2].

Значительную роль в предкриминальных и криминальных ситуациях, по мнению Е. Г. Самовичева [3, С. 50-61], играют акцентуации характера человека. Типы акцентуаций характера, свойственные несовершеннолетним, сходны с взрослыми, но их проявление имеет возрастные особенности, описанные А. Е. Личко [4, С. 325-326]. Нам близко озвученное мнение, и мы полагаем, что метод допроса зависит от доминирующих личностных характеристик, присущих конкретному типу акцентуации характера несовершеннолетнего. Таким образом, если при допросе будут учтены индивидуальнопсихологические особенности несовершеннолетних, то это, безусловно, повысит его эффективность.

Получение объективных и достоверных сведений, относящихся к совершенному преступлению, связано с установлением психологического контакта с несовершеннолетним. Для этого следователи используют различные приёмы воздействия: правило «накопления согласия» [5, С. 374], прием «психологическое поглаживание» [5, С. 
375], демонстрация общности взглядов, оценок, интересов по некоторым вопросам [6, С. 445], наличие устойчивого визуального контакта, а так же наличие естественной мимики, жестов, осанки, сходство манеры общения, принимаемых поз. Необходимость и уместность перечисленных приемов описана в психологической литературе.

\section{ЗАКЛЮЧЕНИЯ}

Таким образом, от каждого следователя и других сотрудников органов внутренних дел кроме знаний криминалистики дополнительно требуются знания в области общей, детской, подростковой и юридической психологии, чтобы эффективно установить психологический контакт с несовершеннолетним при допросе. Неправильный выбор тактического приема сказывается на качестве и полноте полученных показаний и на результатах допроса в целом.

\section{$* * *$}

1. Мухина В. С. Возрастная психология: феноменология развития, детство, отрочество: Учебник для студ. Вузов. - М.: Изд. центр «Академия», 2002. - $456 \mathrm{c.}$

2. Пиз А., Пиз Б. Язык взаимоотношений. Мужчина и женщина. - М.: ЭКСМО-Пресс, 2000.

3. Прикладная юридическая психология: Учеб. пособие для вузов // Под ред. проф. А. М. Столяренко. М.: ЮНИТИ-ДАНА, 2001. - 639 с.

4. Реуцкая И.Е., Бродченко О.И. Психологические особенности допроса несовершеннолетних/ И.Е.Реуцкая, О.И.Бродченко//Прикладная юридическая психология.-2008.-№3.- с. 55-68

5. Самовичев Е. Г. Психологические основы исправления и перевоспитания осужденных. - М., 1985.

6. Собчик Л. Н. Введение в психологию индивидуальности: тактика и практика психодиагностики. - М.: ИПРАН, 1997. - 480 с.

7. Энциклопедия юридической психологии // Под ред. А. М. Столяренко. М.: ЮНИТИ-ДАНА, 2003. - 607 c. 